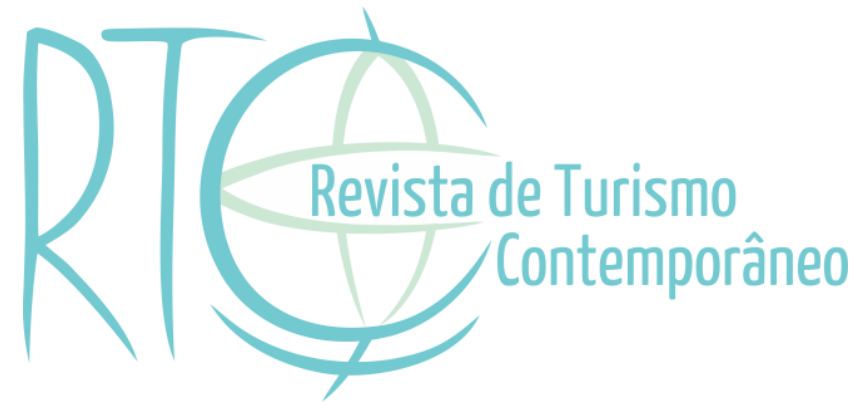

\title{
Analysis of tourism communication by companies on the coast of Piauí - Brazil
}

\section{Análise da comunicação turística por companhias do litoral do Piauí - Brasil}

\section{André Riani Costa Perinotto}

Professor do Curso de Graduação em Turismo da Universidade Federal do Piauí, Teresina/PI, Brasil

E-mail: perinotto@ufpi.edu.br

Adyelle Lima Veras

Graduanda em Turismo pela Universidade Federal do Piauí - UFPI, Teresina/PI, Brasil E-mail: adyelleradeliffc@gmail.com

Thaiane Maria Torres Chaves

Graduanda em Turismo pela Universidade Federal do Piauí - UFPI, Teresina/PI, Brasil E-mail: thaianetorres7@gmail.com 


\begin{abstract}
Tourism has incorporated the new Information and Communication Technologies (ICT) tools for marketing and promotion of tourist destinations. Therefore, the objective of this study was to diagnose the use of ICT by tourism companies in Parnaíba and Luís Correia, both in the state of Piauí, Brazil, addressing their relationship with clients and the use of ICT to advertise products and services. The methodological approach included a literature search and a field survey based on questionnaires and interviews with business owners and administrative managers. Results showed that companies use social networks to connect with clients, particularly tools such as Facebook and Instagram, which are used to advertise destinations. This research should contribute to understanding the use of communication and technology tools adopted by tourism companies.
\end{abstract}

Keywords: Information Technology. Tourism Marketing. Social Networks. Tourism.

\title{
RESUMO
}

Com as novas Tecnologias de Informação e Comunicação (TICs) o turismo apropriou-se dessas ferramentas para o marketing e promoções de destinos turísticos. Em função disso o objetivo desse estudo foi diagnosticar a utilização das tecnologias de informação e comunicação que estão sendo utilizadas pelas empresas turísticas em Parnaíba/PI e Luís Correia/PI, seu relacionamento com clientes e sua utilização para divulgação de seus produtos e serviços. Como procedimento metodológico optou-se pela pesquisa bibliográfica e a pesquisa de campo mediante entrevistas com os empresários e aplicação dos questionários. Os resultados demostraram que as redes sociais são o que as empresas usam para o relacionamento com os clientes, com destaque para ferramentas como o Facebook e Instagram empregadas para divulgação de seus destinos. Acredita-se que essa pesquisa possa contribuir para o entendimento do uso das ferramentas tecnológicas e de comunicação usadas pelas empresas turísticas.

Palavras-chave: Tecnologia da Informação. Marketing Turístico. Redes Sociais. Turismo. 


\section{INTRODUCTION}

Media are essential for tourism companies, because they publicize and promote attractions, products, and services, and encourage and instigate the movement of various people to certain localities. Therefore, through media tourists can access their destinations and all the necessary information to address and fulfill their needs.

Following the reasoning of Marujo (2004, p. 11), media are a tool that, if well-used, can allow public tourism organizations and the private sector to reach their marketing objectives: to promote, to motivate, and to have an impact. Therefore, tourism companies should adopt the most appropriate media for the promotion of products and services to cause impact and influence the desire of the tourist, for instance, to chose a specific destination. From this standpoint, the Internet is an important medium that allows for instant interactions with users. Its importance is explained by the fact that it admits a greater flow of information and decreases the distance between companies and their clients, facilitating contact and dialogue.

With this in mind, Brasil (2000, p. 123) characterizes the Internet as an extremely important tool for the process of commercialization and promotion of tourism products, because online and social network tools support tourism by providing tourists with input and data on places, attractions and tourism services. Accordingly, texts that discuss the importance of communication for tourism were reviewed to support the present study. The objectives of this study were to identify how many and which communication technologies are used by tourism companies on the coast of Piauí state, Brazil, and more specifically in the two main coastal cities, Parnaíba and Luís Correia, and the primary media used by tourism companies to promote their products, services and photographic images. Thus, this paper will address how companies use media and social networks as promotional and informational tools in tourism.

\section{COMMUNICATION AND SOCIAL MEDIA IN TOURISM}

Communication is essential for tourism. With the increase in this type of activity, there is more competition among tourist destinations, drawing a certain degree of attention to investments in advertising, promotion, and communication, all with the goal of attracting tourists. 
Through media, tourists have access to destinations and all the information they need to ensure they feel satisfied and motivated to purchase the service and/or product. Thus, it has been noticed that tourists increasingly opt for independent travel, leading to more searches for information about the destination.

As Dias and Cassar (2005, p. 219) reported, the ultimate goal of marketing communication is to turn the customer into a faithful user of the products and services of the organization, or a regular visitor of a tourist locality. As such, marketing communication actually attracts people through advertising. Thus, marketing consists of planning strategies to commercialize services and products to fulfill customers' desires and needs, and it is also responsible for advertising, promotion, and communication.

Technological advances made it easy to access information through the Internet, social media, images, all available tools, and businesses use them to communicate with their clients and, through digital marketing, to reach a broader audience. On this topic, Gastal (2005, as cited in Perinotto, 2013, p. 5) says that image, in tourism marketing, is voluntarily more important than text. In addition, given technological advances and their resulting popularization, a greater number of customers has access to image manipulation techniques, through cameras and computer software.

Therefore, communication may be said to be one of the main forms of motivating tourists to visit a site, through both photographic images and online publicity, because an image is more attractive and inviting to the tourist's eyes. This clarifies the need for tourism companies to invest in marketing and communication strategies and to have profiles in these digital platforms, which have no direct costs and allow access to people from all over the world.

The use of publicity in digital media is an opportunity to expand the services of the company to make it well-known, to promote its services, and even to establish a relationship with the client. On this topic, Andrade, Barbosa, and Souza (2012) say that the Internet makes a large amount of information available, which an individual can access without having to invest a lot of effort, time, or money. This is because the virtual network brings information to customers in a way that is analogous to what happens in the real world.

According to the European Travel Commision (2013), "The Internet has revolutionised the way in which consumers make their travel decisions. Web-based marketing campaigns have become an increasingly important means of promoting destinations and tourism services." In this globalized scenario, in which the consolidation of the Web as a medium has affected the tourism sector and the behavior of its consumers, it is essential for 
any destination to have an online presence, because service providers need to follow the new trends and technological developments in their publicity. Thus, as the Internet becomes increasingly accessible to the public, new tools emerge and become popular, such as social networks, and begin to also be used as tools to spread information (Cruz, Mota \& Perinotto, 2012, p. 78). With globalization, people are increasingly connected through the Internet and the social networks that are already part of their everyday lives. For this reason, companies should follow this trend and advertise and promote their products and services using these online tools, which, in addition to being fast, also enable interactions with customers regardless of their location.

\section{THE USE OF SOCIAL NETWORKS BY COMPANIES}

Using social networks is a trend that arrived with globalization, and which has gradually conquered space. Today, people around the world are connected to social networks, be it for work or to chat with family or friends. However, beyond that, in tourism social networks are a source of information for customers.

To use social networks for marketing, it is necessary to know the profile of the modern tourist and understand how they use digital tools to plan, buy, experience and share their trips (Borges, 2015, p. 4). Tourists are increasingly aware of these new media and communication tools. Therefore, it is necessary to know the profile and behavior of the tourist, whether they use social networks or other medium.

It is worth mentioning here that social networks consist of people's interactions with others, the formation of groups and their forms of interaction. The largest social network that a person has are friends, family, social circles, and contacts, circles that migrated to the virtual/digital world after the creation of social media, which then became "social networks", such as Facebook, Orkut, Instagram, YouTube, among others. According to Soares, Borges, and Perinotto (2015, p. 49), studies on the behavior and human relations within society happen over time and are dynamic, hence the concepts related to social networks are not new.

With the increasing number of social network users, companies migrated to the virtual environment, with online profiles, websites, blogs, and accounts in Facebook, Instagram, LinkedIn, among others. In addition, there are social networks for all kinds of niche markets, so that there is an opportunity for companies to advertise their product, and a segmentation of the social network. In this sense, according to Guerra, Gosling and Coelho (2014), the Internet standardizes and levels the playing field for those who wish to share 
knowledge and communicate with others. The Internet is an unprecedented tool for the creation of new business models, allowing for the formation of new companies, new ways of working and participation in society.

Companies have realized that if a user who has many followers creates and promotes an outfit or a travel package in their social network, this will certainly attract new customers. This, in turn, increases sales for the company and the number of "likes" that the company receives on their social network profiles, developing a new form of publicity and advertising (increasing follower/customer loyalty) for the company through virtual media, generating digital marketing.

Due to the growing number of websites focused on topics related to the tourism industry, customers are exposed to an almost infinite number of alerts, announcements, promotions, and even information, as an attempt to capture their attention. The social networks themselves contribute for that (Sousa, 2012, p. 4). With new technologies, the customer has instant access to new information, new products, new comments. The company needs to keep track of new ways of reaching this end client, it needs to anticipate new trends. Facebook has become a general social network. In contrast, Instagram and Snapchat have become social networks for segmented profiles, one for photographs and the other for short and informative videos. Thus, Cruz, Barbosa, Mota, and Perinotto (2012, p. 8) state that the use of web tools, such as social networks, to advertise a given location is also very important. To achieve positive results, however, it is necessary to know the target audience and how it interacts in each social network. Based on this assessment, it is possible to define the best way to promote products, provide services or deliver customer assistance, replying to inquiries or offering clarifications.

The ease with which social networks reach all the parts of the world and their low cost motivates many business owners to use them for marketing. As a result, this medium has to learn how to convey the right and responsible (honest) message to the end customer. For publicity to generate the expected effects, it is necessary to research the client that one hopes to reach well, since social networks, in addition to transmitting data and information, generate real-time information for the client and for the company.

\section{METHODOLOGICAL PROCEDURES}

To achieve the objectives outlined in this study, a bibliographical research was used to contextualize the discussion. Tourism companies in Parnaíba and Luis Correia, both cities in Piauí state, Brazil, were chosen as the object of study. The technique and initial process 
used to select businesses was to find companies listed in CADASTUR (the Brazilian registry of individuals and companies operating in the tourism sector). The CADASTUR database is hosted by the Ministry of Tourism of Brazil, and provides access to information about tourism service providers listed in the registry. This process was chosen to ensure that all companies contacted were legally formed.

A questionnaire comprising 20 questions and a few sub-items was developed. The questionnaire was ready for use in October 2015, and on December 11, 2015, a pretest was carried out. For Marconi and Lakatos (1996), pretests should be applied when the questionnaire is close to its final version, using the final format. Cervo and Bervian (2002, p.

48) believe that a questionnaire refers to a way to obtain answers to questions through a formula that the respondents themselves fill.

Between December 2015 and July 2016, field surveys took place in the city of Parnaíba, where a total of 16 questionnaires were administered to listed and contacted companies. The first field survey in Luís Correia occurred in December 2015, for a total of 11 filled questionnaires. The difficulty of getting in touch with the companies was evident, because not all of them replied to emails, and few checked their webpages and social network inboxes. Calls were made to the telephone numbers listed in CADASTUR for each company. However, some employees could not commit to participating, voluntarily or not, because they could not make that decision without the owner or the manager, and asked us to call at another time, when the manager was present.

The present study consists of a comparative analysis of the two main cities on the coast of Piauí, with the goal of identifying the main communication tools used by businesses in these cities. Data collected from the questionnaires were tabulated in Excel using the PivotTable function to create analysis tables with the research results. According to Mattar (1996), verification consists of checking if all questions have been answered, if the openended responses are legible, if the text is understandable, if the respondent followed the instructions for completing the questionnaire correctly, and if the responses are consistent.

\section{RESULTS AND DISCUSSION}

As a result of this research, we found that social networks currently are the most commonly used tools for customer/vendor communication and for the promotion of products and services on the coast of Piauí. The following results were observed from the data obtained through the research: 
Fig. 1: Social networks used

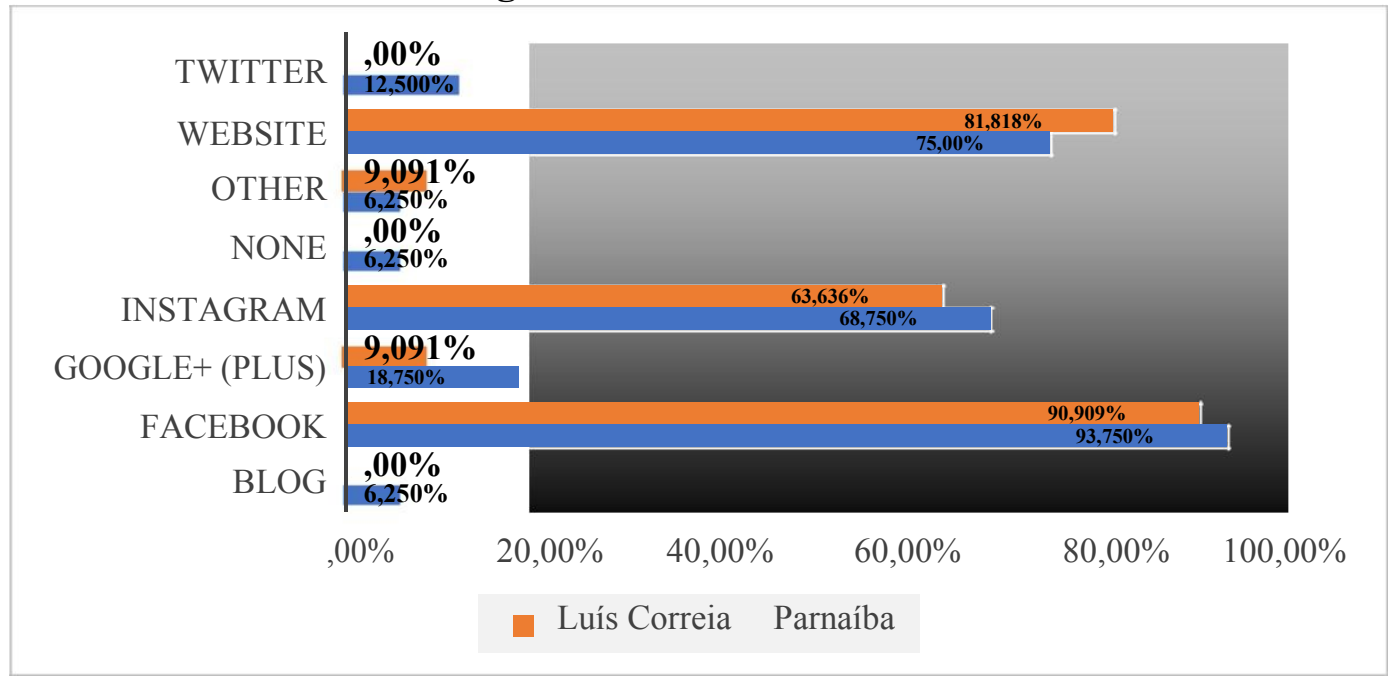

Facebook is the social network most used by companies in both municipalities to advertise attractions and services (Fig. 1). We can also infer that social networks are gaining more space over time, since companies have begun to use them as marketing tools. Cruz et al. (2012, p. 14) believe that in the travel and tourism sector, tourists' opinions and recommendations are extremely important for the growth of a company, because as they travel, they take pictures and shoot videos of a particular site, which may generate interest from other users after being uploaded to social networks.

The second item in Fig. 1 is websites, followed by Instagram, a social medium that consists exclusively of photographs and videos, which makes a significant contribution to the propagation and development of tourism. Again according to Cruz et al. (2012, p. 12), in the case of tourism, social networks exert a fundamental influence. This influence occurs from the moment a given product or a tourist destination is advertised; publicity may take several forms, such as banners on websites, and may also take place through audience participation and interaction in social networks such as Orkut, Facebook, Twitter, Flickr, and others.

Besides Facebook, other media, in addition to social networks, may be used for publicity by companies (Fig. 2).

Fig. 2: Forms of communication 


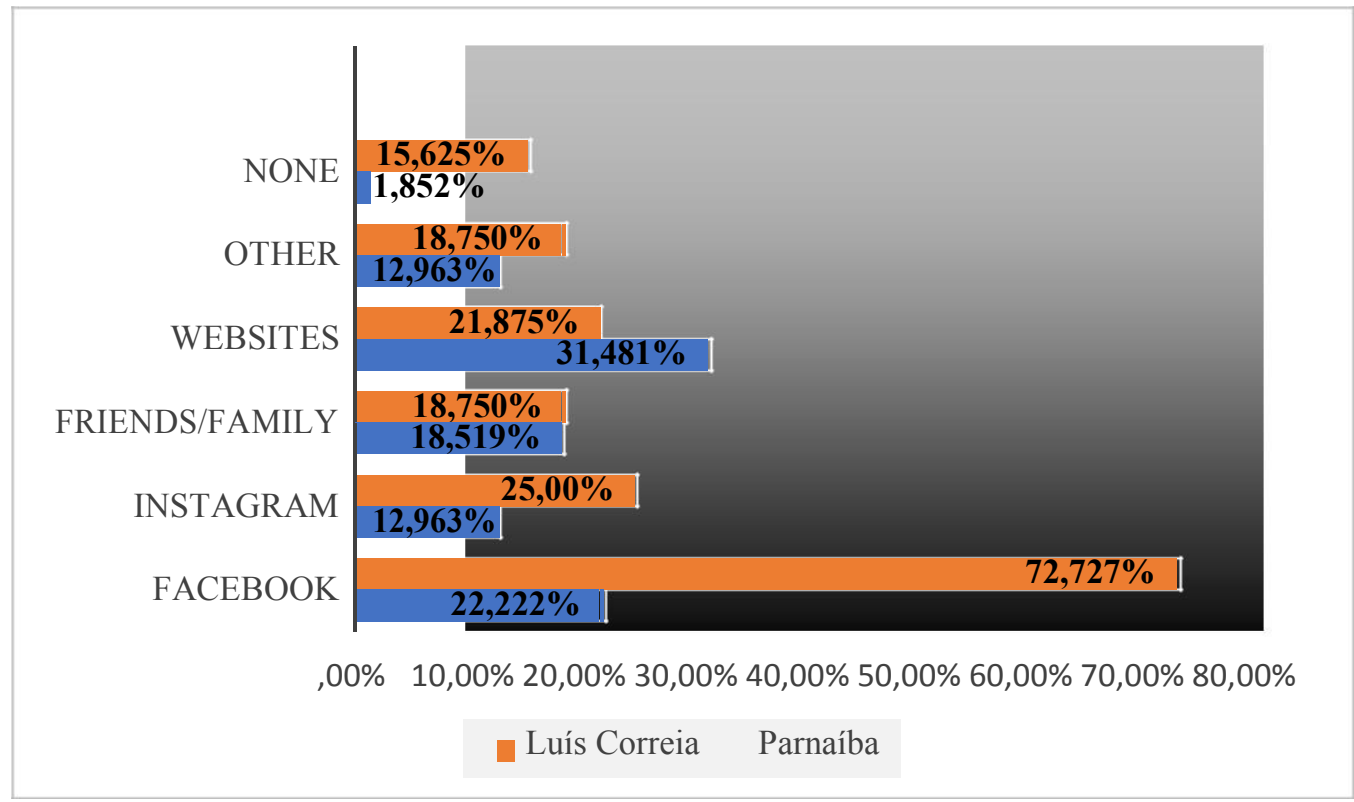

Figure 2 shows that word of mouth, including electronic word of mouth (e-WOM) carried out through social media, is still used by businesses, with an incidence of $18.5 \%$ in Parnaíba and $18.8 \%$ in Luís Correia. It is imperative to note that word of mouth continues to be important for tourism. Its positive or negative impact is relevant and, once linked to social networks, it generates a greater impact through e-WOM. According to Mendes Filho and Carvalho (2014, p.2), with the growth of the Web, where users are the main source of dissemination of online information, the latter is generated by the Internet users themselves, facilitating publicity through e-WOM.

A larger percentage of Parnaíba companies had websites compared to Luís Correia. It is evident that ICT are important and are used as a marketing activity. This substantiates the degree to which these technologies have consolidated as communication and promotion tools, be it for products, brand, or services. Thus, Flores, Cavalcante and Raye (2012, p. 329) state that ICT have radically changed the efficiency of tourism organizations, business management and market orientation, in addition to the way consumers interact with these organizations. Thus, they have helped improve service quality and have contributed to improve customer/traveler satisfaction, allowing them to access reliable, accurate information, in addition to spending a minimal amount of time and money to book reservations. 
Fig. 3: The use of images for publicity

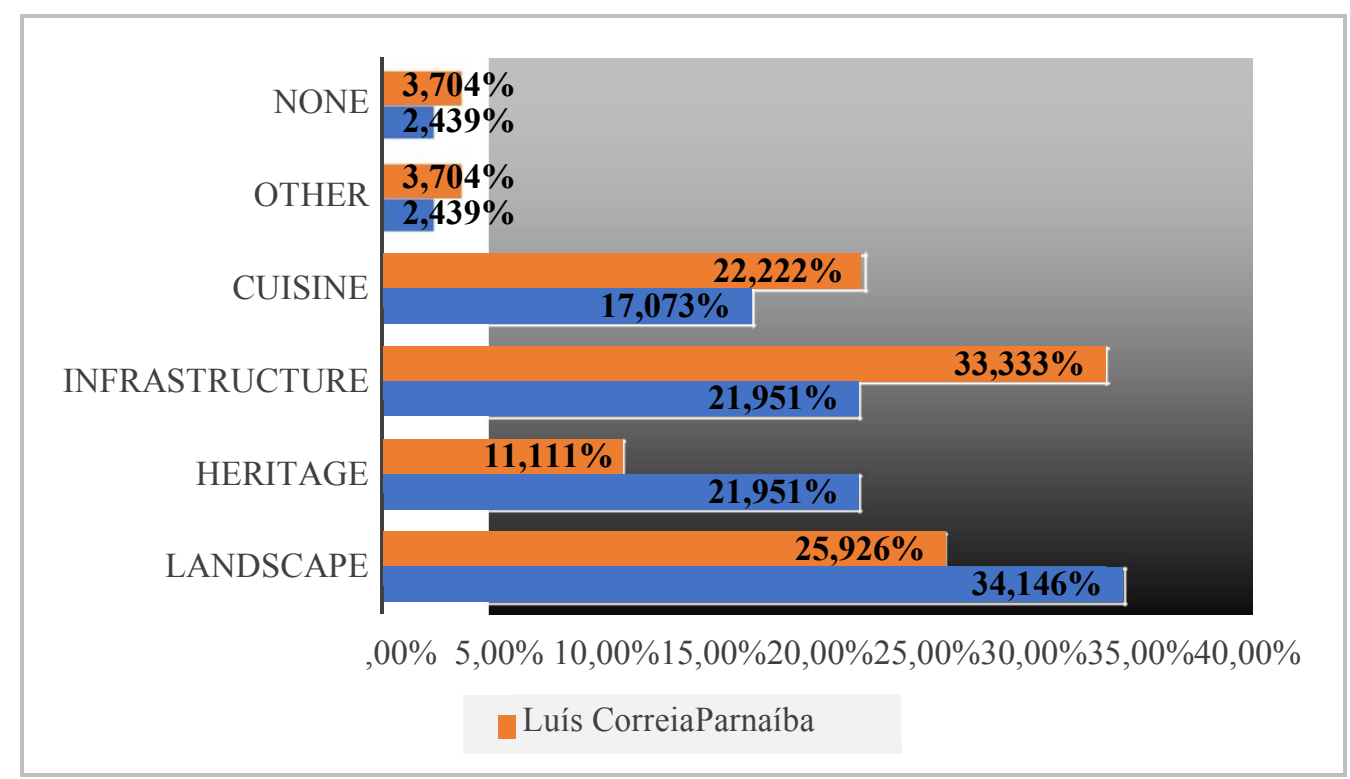

As observed in Fig. 3, most images used by companies portray landscapes and infrastructure. Thus, for Perinotto (2013, p. 4), it is important to develop an image of the tourist destination based on photographs that represent, in their complexity, aspects of the locality (landscape, climate, nature, culture, cuisine, arts and folklore, in addition to history, customs and local habits).

Promoting these photographs is important for the decision-making process of the tourist, so that the tourist holds all the necessary information about a locality when traveling somewhere.

Fig. 4: Location map of the company

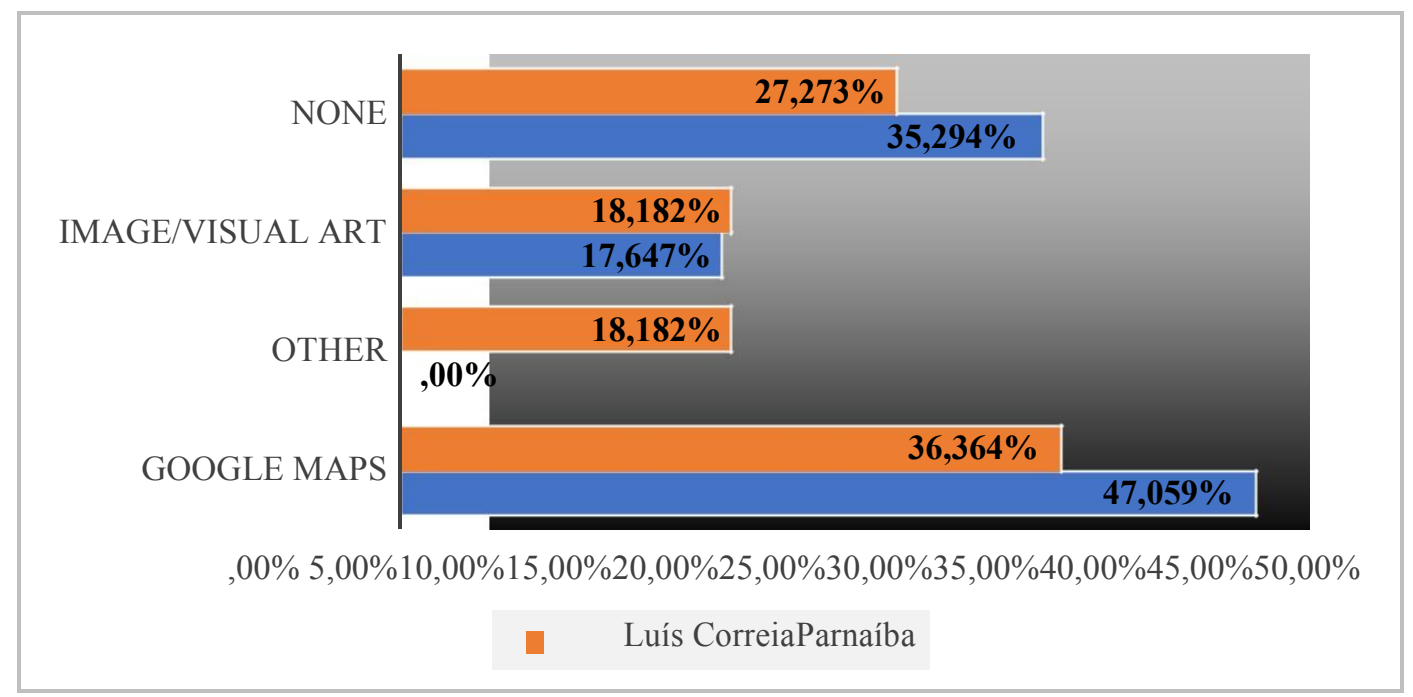


Displaying the location of the company on the website is ideal for all businesses, since the first information that tourists look for is the place where the business is located. Most companies in Parnaíba and Luís Correia display some form of location on their websites (Fig. 3). However, some of the companies do not provide their location, which is negative point, because the website is the information portal of the company. If the website does not include the location, clients are unable to obtain all the necessary information to plan their trip.

Emídio, Celestino and Perinotto (2014, p. 3) state that with current technological advances, it is increasingly simple to access information, maps, images, among others, from regions around the world, and the Internet is the easiest way to access information. In addition to building trust in customers' minds that the company does exist, this is the first place where they will look for information, which should be as complete as possible to satisfy the needs of the clients.

Fig. 5: Location map of the attractions

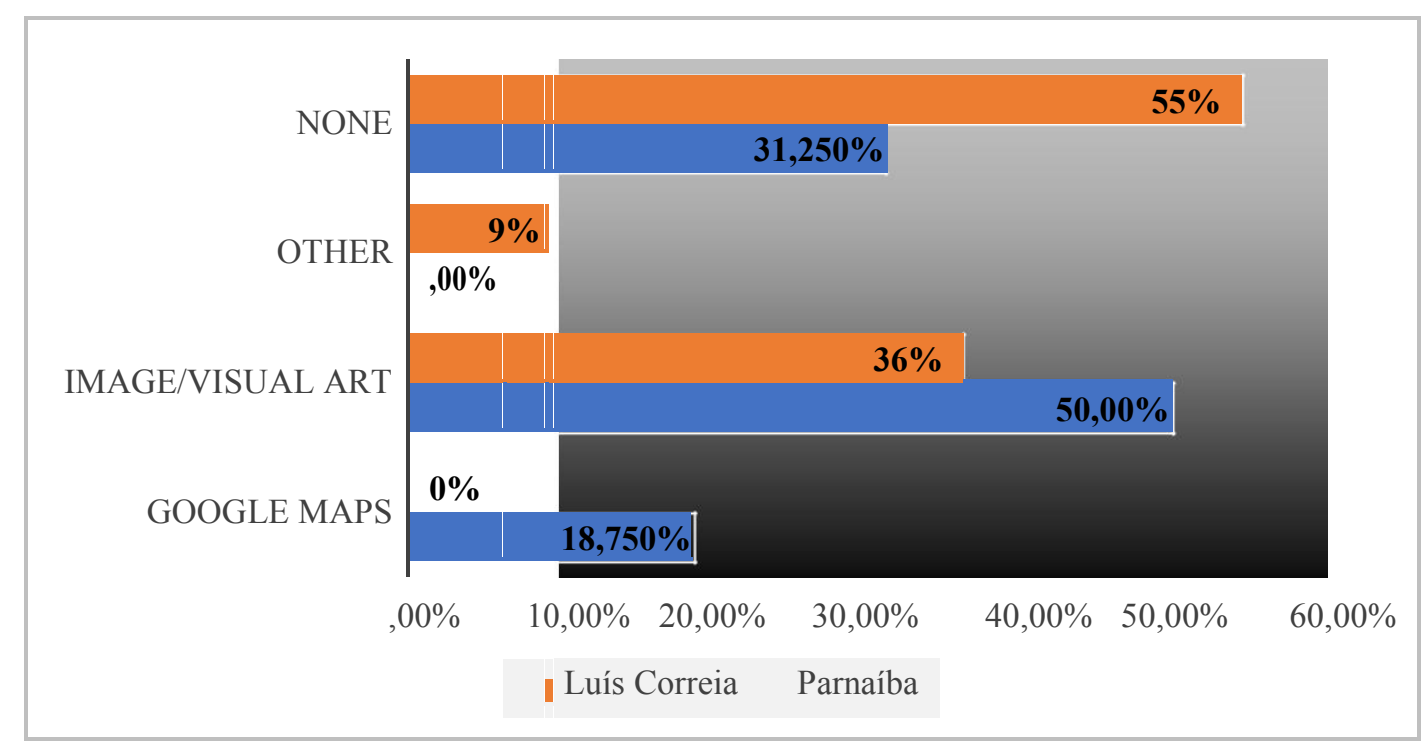

Figure 5 shows that $55 \%$ of the businesses that filled the questionnaire in Luís Correia do not offer a location map of the tourist attractions in the region, which is a somewhat negative result for the municipality, since tourists will not be able to know what attractions exist in the visited region. Within this context, Flores, Cavalcante and Raye (2012, p. 70) remark that the tourism marketing mix is a bridge that facilitates the contact between tourism organizations (locality, suppliers, carriers, travel agencies, among others) and the tourism environment. This connection or partnership between the business community and the 
public organizations that promote tourist attractions does not exist. In contrast, $50 \%$ of companies in Parnaíba provide a map as visual art image.

Therefore, it is apparent that tourists travel to learn about the culture and the food and see what the site has to offer. To this end, companies should have promotional materials about local tourist attractions, which may give an edge to the company. As emphasized by Cruz, Camargo and Guzela (2007), tourists' reasons and motivations for choosing a locality to visit on vacation are directly related with the tourism appeal of the destination, which may be cultural, medical, business, events, sun and sand, sports, ecotourism, or religious. This appeal, in turn, is closely related to natural, man-made, cultural, and social attractions that already exist in the tourist destinations.

Fig. 6: Sharing of user-generated content

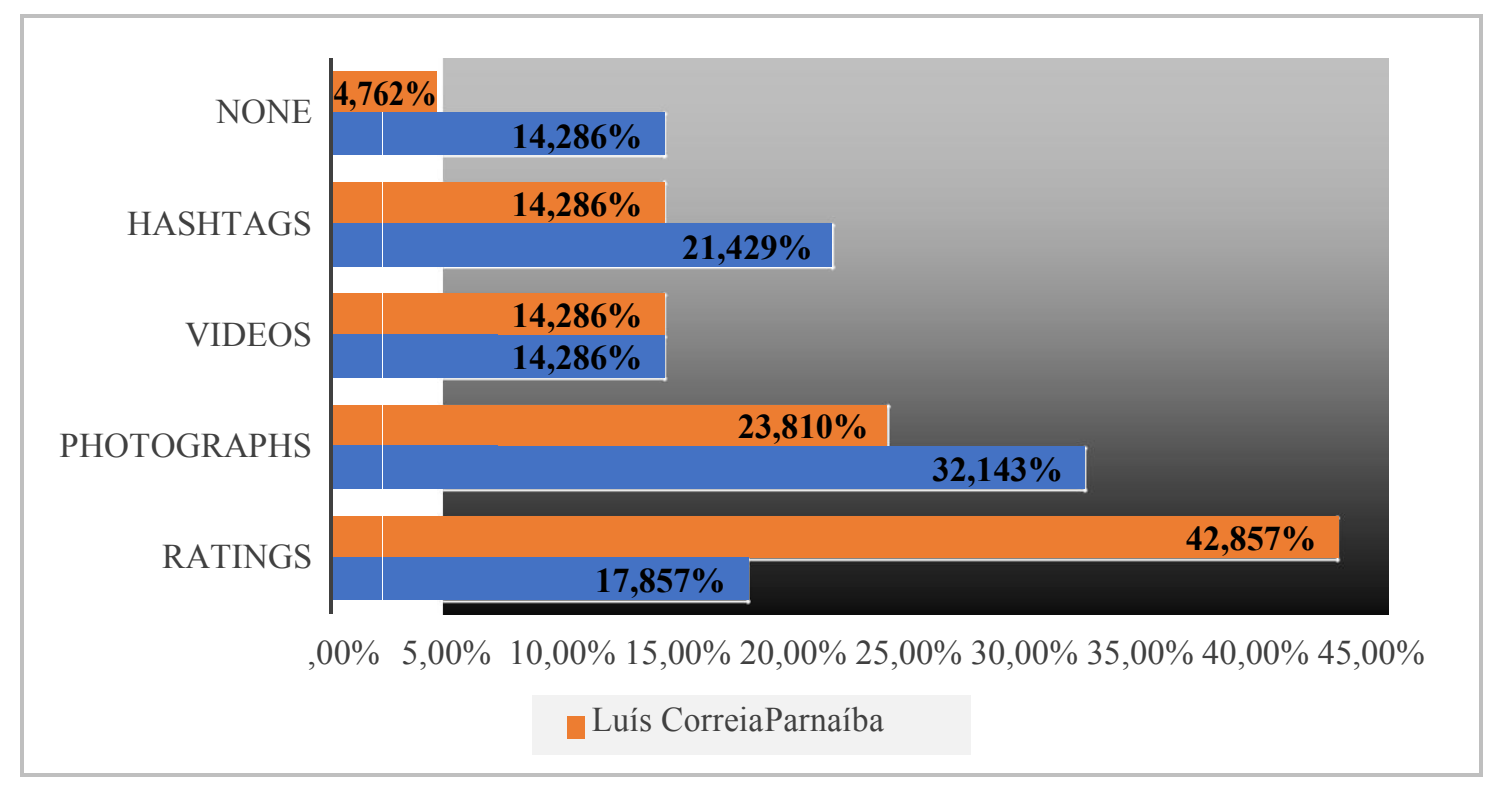

Companies encourage their clients to share UGC (user-generated content). Usergenerated content allows companies and clients to examine what is being said about the company and the opinion of those who purchased a product or service. Thus, the company may learn how their service is doing based on people's comments, and these comments, good or bad, may influence the choice of destination by the client. Thus, Gretzel and Yoo (2008 as cited in Mendes Filho, 2014, p. 611) state that UGC allows Internet users to make comments in many different ways, such as pictures, videos, podcasts, ratings, reviews, articles, and blogs. Thus, user-generated content is a common tool of websites such as TripAdvisor, where it consists of information contributed by users about places they have already been to and tourist sites they have already visited, through ratings and comments. 
Fig. 7: Hashtags in social networks

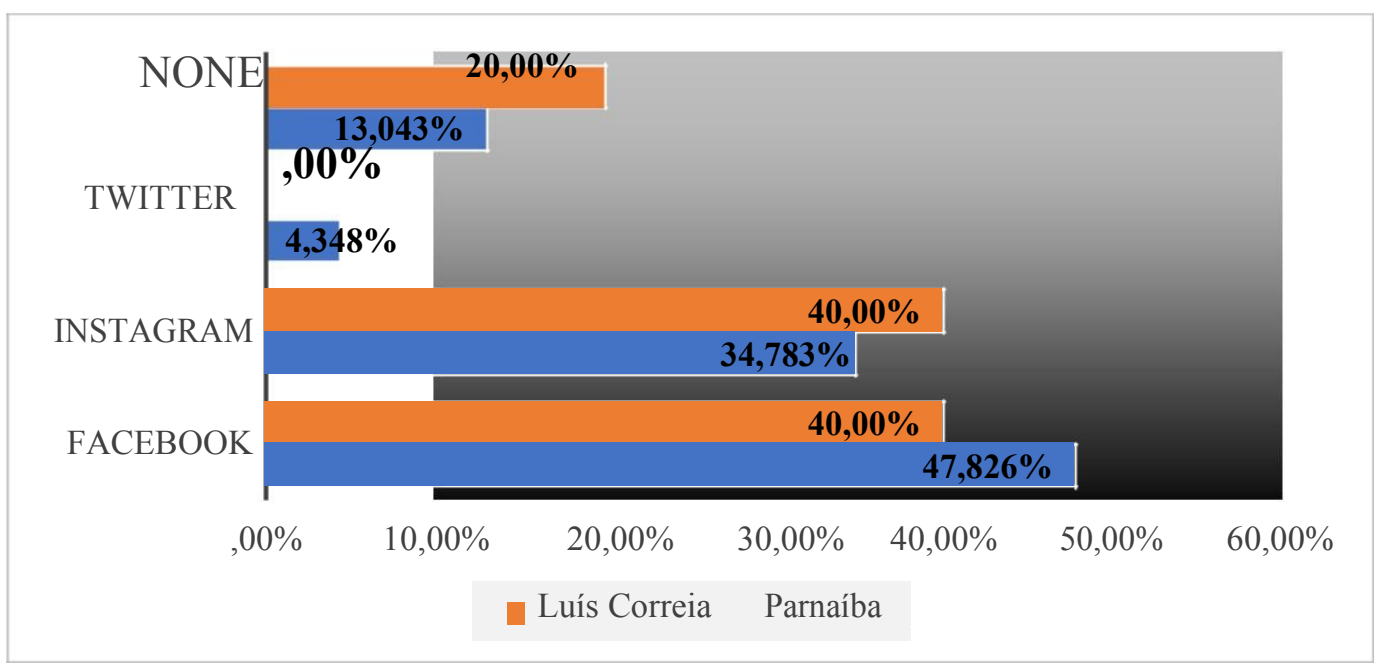

Facebook and Instagram are the most used social networks with hashtags (Fig. 7). The use of hashtags is important to identify popular topics and what is being said about the company. According to Paine (2011, as cited in Thomaz, 2014, p. 88), an alternative to realtime monitoring of social media chat is the creation and use of hashtags to assist in the collection and monitoring of references to an event or subject. Facebook, Twitter, and YouTube are social media tools used to promote services, and allow travelers to seek and share tourism information on the Internet (Thomaz, Biz \& Gândara, 2013).

Fig. 8: After-sales service evaluation

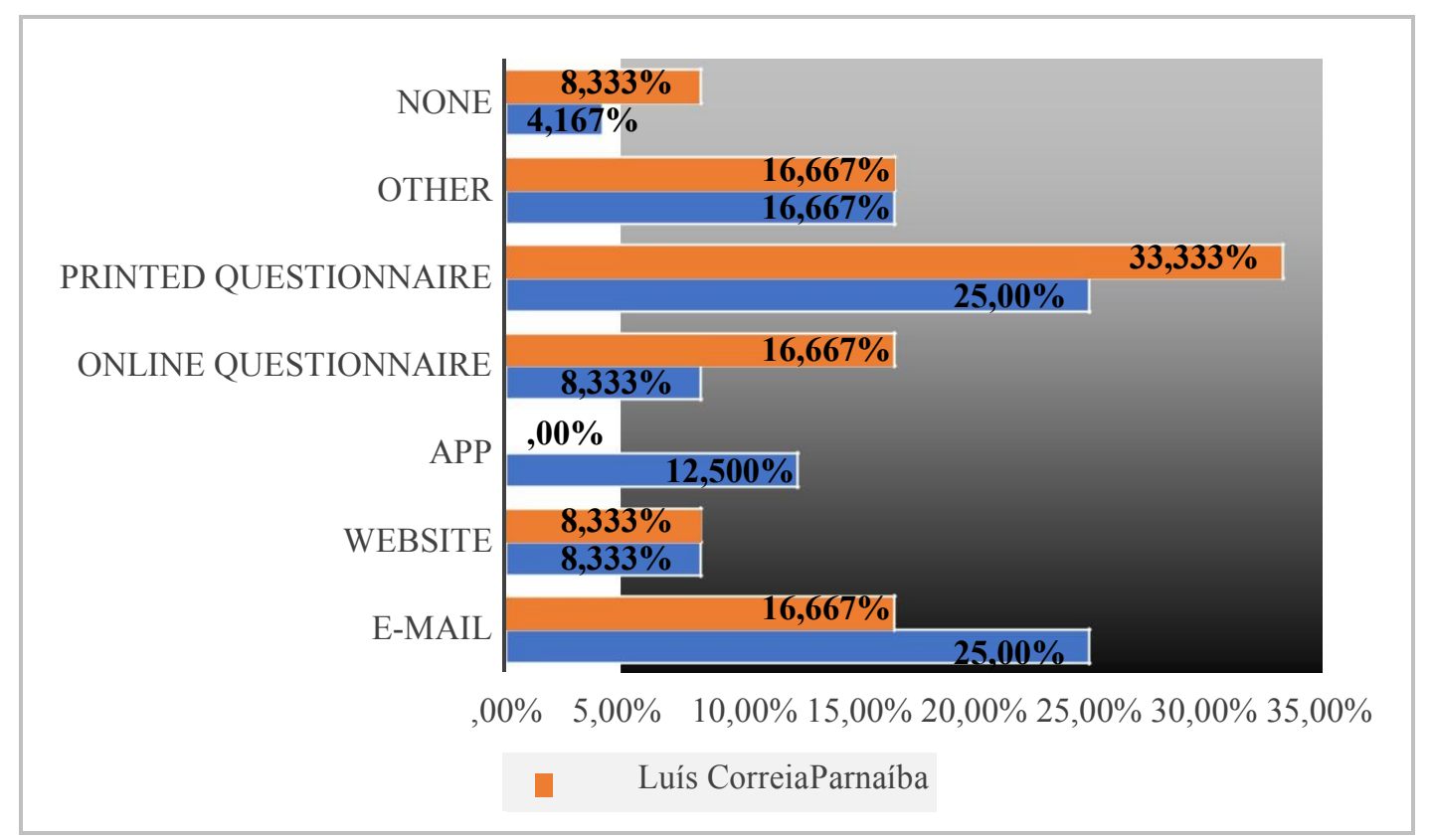


As seen in Fig. 8, most companies evaluate printed materials after providing services, using printed questionnaires. This could be done online because, in addition to the low cost for the company, it might reach additional clients with positive information. It is important to remember that, with the Internet, one needs to be more careful, because negative information may also reach the client. However, positive feedback from some clients may generate a greater client flow, in the future, towards the company. According to Cruz et al. $(2012$, p. 6), the Internet has become a more appropriate channel to distribute information through data, photos, videos, sounds, and virtual images, and in real time, therefore reaching millions of people at a low cost.

Following the results obtained from the cities on the coast of Piauí, we noted that advertising occurs through the Internet and social networks, which are used not only for the dissemination of services, but also for communicating with customers. However, Luís Correia surpassed Parnaíba in some media, despite the fact that the latter has more tourist-oriented infrastructure such as accommodations, agencies, etc.

Companies in both municipalities do not differ in terms of media used to promote products and services and attract prospective tourists. Accordingly, their tourist profiles are likely similar. The responses to one of the questions in the questionnaire, whether the company had a marketing plan, were noteworthy, because a company's customer profile and target client are detected during planning. In addition, these companies had no qualified marketing employees.

Also based on the data collected here, $45.4 \%$ of the companies in Luís Correia have no marketing plan, and in Parnaíba this number is $57.1 \%$, leaving much to be desired on the technical side when it comes to integrating theory and practice. Thus, it is important for the company to implement a marketing plan to verify if their strategies are reaching their goals, and if their clients feel motivated by the products or services advertised.

In terms of photographic images, businesses in Parnaíba tend to use more landscape photos of the region, in contrast to Luís Correia, where infrastructure is highlighted in advertisements. This result also demonstrates the difference between the profiles of the companies studied in each municipality. Since Parnaíba has greater infrastructure to cater to tourists, there is a large number of agencies and lodging options. Luís Correia, on the other hand, mostly has accomodations, because the city is less well developed in terms of private tourism businesses. 
Location maps of the companies in websites are not used in Luís Correia, and in Parnaíba they are displayed as images and visual art. In addition, it is not known how the products are distributed, or if the lodging establishments have partnerships with agencies to promote products.

\section{CONCLUSION}

Although the results of the questionnaires demonstrate that companies do use the Internet for publicity, it is not possible to say whether the expected results of this promotion have been achieved, because for that it would be necessary to have a monitoring report of the social networks, in addition to tracking sales made by companies after adopting new, or different, media.

Going back to the objectives put forward in this article, with respect to the objective of identifying the communication technologies used by tourism companies on the coast of Piauí, the main medium detected was Facebook, and Parnaíba was the municipality where more companies used social network. In terms of the objective of identifying the main media/tools used by tourism companies, Instagram was found to be the main tool, demonstrating the importance of photographic images for the activity of tourism companies.

After checking the use of social networks as a tool for promoting products and services by tourism companies, we found that most businesses use social networks, both to promote their products and for sales. When assessing the relevance of Communication Technology for business marketing, its importance was revealed through websites, which offer information about the company to tourists and represent a way to promote the company online.

We hope that this work will contribute for the understanding of the main information and communication technologies (ICT) used on the coast of Piauí, and that it becomes a source for research and contributes for future projects.

\section{REFERENCES}

Andrade, M. B., Barbosa, M. L. A., \& Souza, A. G. (2012). Busca por informações e imagem de destinos turísticos: Análise dos estímulos ofertados nos websites de órgãos governamentais de turismo dos principais estados do Nordeste brasileiro [Information and image search on tourist destinations: An analysis of the incentives given on the websites of governmental tourism organizations in the largest states in Northeastern Brazil]. TURyDES. Revista de Investigación, Turismo y Desarrollo Local, (13). 
Borges, M. (2015) Mídias sociais para empresas turísticas [Social media for tourism companies]. São Paulo. Retrieved from http://agentenoturismo.com.br/.

Brasil. (2010). Segmentação do turismo e o mercado [Tourism segmentation and the marketplace]. Brasília: Ministério do Turismo.

Cervo, A. L., \& Bervian, P. A. (2002). Metodologia cientifica. [Scientific Methodology]. (5th ed.). São Paulo: Prentice Hall.

Cruz, G., Camargo, P., \& Guzela, M. (2007). Fotografia e suas interfaces para o desenvolvimento da imagem de um destino turístico [Photography and its interfaces for the image development of a tourist destination]. Anais do IX SIT - Seminário Internacional de

Turismo, Curitiba, Brazil. Retrieved from http://www.uesc.br/cursos/pos_graduacao/mestrado/turismo/artigos/fotografia_imagem.pdf.

Cruz, V. L. L., Barbosa, V. S., Mota, K. M., \& Perinotto, A. R. C. (2012). Redes sociais como estratégia de marketing turístico: O Facebook e a região norte do estado do Piauí-Brasil [Social networks as tourism marketing strategies: Facebook and the north region on Piauí state, Brazil] TURyDES Revista de Investigación, Turismo y Desarrollo Local, 5(13), 1-25.

Cruz, V. L. L., Mota, K. M., \& Perinotto, A. R. C. (2012). edes sociais na internet estrat ia para a di 1 a o das potencialidades do $\mathrm{t} r$ sticas do ia - Brasil [Internet social networks: A strategy for touristic potential disclosure of Piauí, Brazil]. Rosa dos Ventos, 4(1), 77-88.

Dias, R., Cassar, M. (2008). Fundamentos do marketing turístico [Fundamentals of tourism marketing]. Pearson Prentice Hall, São Paulo.

Emídio, L. P. B., Celestino, I., \& Perinotto, A. R. C. (2014). A imagem fotográfica e sua influência na escolha do destino turístico: Um estudo em Barra Grande - PI [The photographic image and its influence on the choice of tourist destination: A study in "Barra Grande"'-PI]. TURyDES Revista de Investigación, Turismo y Desarrollo Local, 7(16).

European Travel Commision. NewMedia TrendWatch. (2013). Retrieved from http://www.newmediatrendwatch.com/.

Flores, L. C. S., Cavalcante, L. S., \& Raye, R. L. (2012). Marketing turístico: Estudo sobre o uso da tecnologia da informação e comunicação nas agências de viagens e turismo de Balneário Camboriú (SC-Brasil) [Tourism marketing: A study of the use of information and communication technology in travel agencies and tourism of Balneário Camboriú (SC, Brazil)]. Revista Brasileira de Pesquisa em Turismo, 6(3), 62-79.

Guerra, A. C., Gosling, M., \& Coelho, M. de F. (2014). Redes Sociais: Um jornal on-line como fonte de informação especializada em turismo [Social networks: An online newspaper as a source of specialized information on tourism]. Revista Brasileira de Pesquisa em Turismo, 8(3), 403-418. São Paulo.

Marconi, M. D. A., \& Lakatos, E. M. (1996). Técnicas de pesquisa: Planejamento e execução de pesquisas, amostragens e técnicas de pesquisas, elaboração, análise e interpretação de dados [Research methods: Planning and executing research, sampling and research methods, data preparation, analysis and interpretation]. ( $3^{\mathrm{a}}$ ed.). São Paulo: Atlas. 
Marujo, M. N. N. V. (2004). Turismo - meios de comunicação e promoção: O caso da Madeira [Tourism - communication and promotion media: The case of Madeira] (Unpublished master's thesis). University of Évora, Évora, Portugal.

Mattar, F. N. (1996). Pesquisa de marketing: Edição compacta [Marketing research: Compact edition]. São Paulo: Atlas.

Mendes Filho, L., \& de Carvalho, M. S. D. (2014). Factores que influyen en el uso del contenido generado por el usuario en internet: Un estudio preliminar con viajeros brasileños [Factors that influence the use of user-generated content on the Internet: A preliminary study with Brazilian travelers]. Estudios y Perspectivas en Turismo, 23(3), 607-625.

Perinotto, A. R. C. (2013). Investigando a comunicação turística de Parnaíba/PI-Brasil: Internet e redes sociais, descrição e análise [Investigating tourist communication in Parnaíba, PI, Brazil: The Internet and social networks, description and analysis]. TURyDES-Revista de Investigación en Turismo y Desarollo Local, 6(15).

Soares, D. R. S., Borges, D. M., \& Perinotto, A. R. C. (2015). YouTube e turismo: O Delta do Parnaíba nessa relação [YouTube and tourism: The Parnaíba delta in this relationship]. Revista SODEBRAS, 10(115), 48-53.

Sousa, C. (2012). A influência da Internet na escolha de um destino turístico [The influence of the Internet on the choice of a tourist destination]. Cogitur Journal of Tourism Studies, (5).

Thomaz, G. M., Biz, A. A., \& Gândara, J. M. G. (2013). Innovación en la promoción turística en medios y redes sociales: Un estudio comparativo entre destinos turísticos [Innovation in tourism promotion in media and social networks: A comparative study of tourist destinations]. Estudios y Perspectivas en Turismo, 22(1), 102-119.

Thomaz, G. M. (2014). Processo de mineração de conteúdos em mídias sociais para auxílio na gestão de destinos turísticos [The process of mining content in social media to help manage tourist destinations] (Unp blished master's thesis). Federal University of Paraná, Curitiba, Brazil. 